\title{
Potassium and Nitrogen Fertilization vs. Trace Element Content of Maize (Zea mays L.)
}

\author{
Mirosław Wyszkowski ${ }^{1}$ (D) and Marzena S. Brodowska ${ }^{2, *}$ \\ 1 Department of Environmental Chemistry, University of Warmia and Mazury in Olsztyn, Łódzki 4 Sq., \\ 10-727 Olsztyn, Poland; miroslaw.wyszkowski@uwm.edu.pl \\ 2 Department of Agricultural and Environmental Chemistry, University of Life Sciences in Lublin, \\ Akademicka 15 Str., 20-950 Lublin, Poland \\ * Correspondence: marzena.brodowska@up.lublin.pl
}

Citation: Wyszkowski, M.; Brodowska, M.S. Potassium and Nitrogen Fertilization vs. Trace Element Content of Maize (Zea mays L.). Agriculture 2021, 11, 96. https:// doi.org/10.3390/agriculture11020096

Academic Editors: Jose Luis Gabriel and Diana Martín-Lammerding Received: 31 December 2020

Accepted: 21 January 2021

Published: 24 January 2021

Publisher's Note: MDPI stays neutral with regard to jurisdictional claims in published maps and institutional affiliations.

Copyright: (c) 2021 by the authors. Licensee MDPI, Basel, Switzerland. This article is an open access article distributed under the terms and conditions of the Creative Commons Attribution (CC BY) license (https:/ / creativecommons.org/licenses/by/ $4.0 /)$.

\begin{abstract}
This research was conducted to study the impact of potassium and nitrogen fertilizers on the trace element content of maize (Zea mays L.). Higher doses of potassium fertilizer led to a linear increase in cadmium, lead, nickel, zinc, and manganese content, and to lower Fe:Zn and Fe:Mn ratios. Moreover, cobalt level increased in maize upon the lower doses and decreased upon the higher doses of potassium. The impact of potassium fertilizer on the levels of other elements (iron and chromium) in maize was determined by the fertilizer dose and, in particular, by the supply of additional nitrogen. Potassium fertilization led to a higher bioconcentration (BCFactor) of most of the trace elements in the aerial parts of maize. Nitrogen fertilization led to increased contents of manganese and iron, increased Fe:Zn and Fe:Mn ratios, and decreased contents of cadmium, lead, nickel, and cobalt in maize. Compared with potassium, nitrogen fertilization produced less consistent changes in bioconcentration factors for trace elements in the aerial parts of maize.
\end{abstract}

Keywords: nitrogen fertilization; potassium fertilization; Zea mays L.; trace elements

\section{Introduction}

Producing high-quality agricultural crops requires more than just optimum levels of essential macronutrients in the soil that have the strongest impact on plants. Trace elements also play an important role in this respect [1]. Most of them are beneficial-they are plant components and they are involved in enzyme synthesis and in activation of numerous enzymatic processes, and they serve as electron carriers, thus affecting the chemical composition of plants, as well as the crop yield [1,2]. According to current research, cadmium, lead, mercury, and arsenic are some of few trace elements that are not physiologically beneficial to plants [3]. Trace elements in arable lands originate from air pollutants, mostly those emitted around industrial sites — especially various factories, power plants, mines, and transport routes [3,4]. In areas located further away from industrial sources of air pollution, trace elements are provided through fertilization with sewage sludge and irrigation with sewage effluent $[3,5,6]$, mineral, natural, and organic fertilizers, and plant protection agents [3,7]. Fertilizers and other chemicals used in agriculture must comply with the applicable legal standards [8]. Hence, soil trace element limits are unlikely to be exceeded in unpolluted areas. Any additional supply of trace elements (e.g., in the form of mineral fertilizers) may result in overshoot the limits for the soil and plants in areas with increased concentrations of heavy metals. Trace elements may then be passed on further along in the trophic chain through the crops, eventually entering human bodies and, thus, posing a potential threat to human health [3,9]. Long-term consumption of toxic trace elements (especially heavy metals) poses an adverse effect on health of people, although the harmful effects may only become apparent after several years [10]. Heavy metals are not only dangerous for the safety of agricultural products. They are also harmful to the immune, reproductive, and nervous systems of living organisms [4]. Average trace element 
levels in natural soils around the world are determined by type of soil and can vary widely: from less than $1 \mathrm{mg}$ for cadmium, from a few to less than $20 \mathrm{mg}$ for cobalt, from 10 or so to dozens mg for nickel, copper, lead, chromium, and zinc, several hundred mg for manganese, and from a few to several thousand $\mathrm{mg}$ for iron (per $\mathrm{kg}$ soil) [11]. The use of mineral fertilizers, especially the nitrogen-based ones, is a major contributor to the transfer of heavy metals and many other toxic contaminants in soil-plant systems, mainly through changes in soil acidity [12,13], microbial counts, and enzymatic activity [14], which in turn impacts the bioavailability of heavy metals.

The use of fertilizers and agents can be one of the main drivers of excessive heavy metal accumulation in the soil. Bai et al. [15] showed increased levels of cadmium, chromium, copper, nickel, zinc, and arsenic in intensively fertilized greenhouse soil relative to soils used in traditional farming. Thus, avoiding the use of mineral and organic fertilizers, as well as plant protection products rich in heavy metals, can be beneficial by preventing excessive heavy metal accumulation in the soil [15].

Liu et al. [16] showed that contamination of farming soils with trace elements-including cadmium, lead, mercury, chromium, zinc, and copper-was mainly attributable to farming practices, in particular to wastewater use for irrigation. Soil parent material had a strong effect on arsenic and nickel content in soil. Importantly, however, levels of these elements did not exceed acceptable limits for agricultural soils.

In a study by Czarnecki and Düring [17], a 14 year mineral fertilization treatment (nitrogen, phosphorus, NP, and NPK) led to increased levels of some trace elements in soil (cadmium, lead, zinc, copper, and manganese). The findings also showed lower soil $\mathrm{pH}$, increased carbon levels, and improved cation exchange capacity in soil. Ajayi et al. [18] found similar associations while examining a 33 year mineral fertilization treatment, which produced higher trace element content in soil compared with unfertilized plots. The trace element levels in soil were found to be progressively lower in the order $\mathrm{Mn}>\mathrm{Zn}>\mathrm{Pb}>$ $\mathrm{Cu}>\mathrm{Cd}$. However, it should be noted that the long-term use of mineral fertilizers did not increase the content of these metals. In a study by Wyszkowski and Brodowska [7], nitrogen fertilization increased some trace element levels, e.g., zinc, iron, copper, manganese, chromium, and cobalt, with simultaneous decreases in cadmium, nickel, and lead. Potassium fertilizers caused an increase of cadmium and lead levels, while an inverse effect was found on chromium and iron levels in soil.

Miner et al. [19] argued that nitrogen fertilization could not be a significant determinant of overall trace element levels and forms in soil, which was instead linked to the organic carbon content and soil fertility, and usually decreased with depth (especially in the case of copper and manganese).

When starting the research, it was hypothesized that the effect of nitrogen fertilization on the content of trace elements in maize biomass for silage was determined by the dose of potassium. Additionally, it was assumed that a greater accumulation of trace elements in maize biomass would occur in plants fertilized with higher doses of macronutrients.

The general objectives were to identify the relationship between nitrogen supply to plants and the content of trace elements, and to determine the relationship between increasing doses of potassium at one level of nitrogen fertilization for the accumulation of selected trace elements.

To verify these assumptions, studies were carried out to determine the impact of increasing potassium fertilization in interaction with nitrogen fertilization on the content of trace elements in maize (Zea mays L.). Maize has the capacity to accumulate large quantities of heavy metals. Heavy metal uptake by plants is determined by multiple factors, e.g., metal chemical species, soil texture, cation exchange capacity, and, most significantly, soil $\mathrm{pH}$. Maize grown in soil contaminated with trace elements can serve as a hyperaccumulator [4]. 


\section{Materials and Methods}

\subsection{Methodological Design}

The research was conducted in a vegetation hall on soil sourced from a typical arable humus horizon of brown earth (Eutric Cambisol), with a particle size distribution classified as sand $(90.28 \%$ of $>0.05 \mathrm{~mm}$ sand, $7.86 \%$ of $0.002-0.05 \mathrm{~mm}$ silt, and $1.86 \%$ of $<0.002 \mathrm{~mm}$ clay), according to the World Reference Base for Soil Resources [20]. The properties of the soil were presented in a previous paper [7]. The study was conducted in two blocks: at lower $(\mathrm{N}-130 \mathrm{mg} / \mathrm{kg})$ and higher $(\mathrm{N}-170 \mathrm{mg} / \mathrm{kg}$ soil) nitrogen inputs. The effect of applying progressively higher doses of potassium was compared to control (without $\mathrm{K}$ ) in two series with nitrogen. Three doses of potassium $\left(\mathrm{K}_{2} \mathrm{O}-140,190\right.$, and $240 \mathrm{mg} / \mathrm{kg}$ of soil) were introduced into the soil as potassium sulfate $\left(\mathrm{K}_{2} \mathrm{O}-500 \mathrm{~g} / \mathrm{kg}, \mathrm{SO}_{3}-450 \mathrm{~g} / \mathrm{kg}\right)$, whereas nitrogen was introduced as a solution of urea-ammonium nitrate $(\mathrm{N}-280 \mathrm{~g} / \mathrm{kg})$. The first dose of both fertilizers (half the full dose) was introduced into the soil once the experiment was established. To ensure optimal plant growth, equal amounts of phosphorus were applied to each pot- $85 \mathrm{mg} \mathrm{P}_{2} \mathrm{O}_{5} / \mathrm{kg}$ of soil (Superfosdar40). Maize (Zea mays L.) served as the study crop for testing the effect of potassium and nitrogen fertilizers. Maize is a typical plant cultivated in our country. The experiment was carried out in triplicate in polyethylene pots (height $-25 \mathrm{~cm}$, diameter from $19 \mathrm{~cm}$-bottom to $24 \mathrm{~cm}$-top) with soil $(9 \mathrm{~kg})$ thoroughly mixed with mineral fertilizers, as per the study scheme. Next, maize was sown. The density of maize was eight plants per pot. The second half of the doses of potassium and nitrogen fertilizers was added to soil at the 4-6-leaf stage. The soil capillary water capacity was $60 \%$. The meteorological parameters were typical for the period April-July (average air temperature-April $8.6^{\circ} \mathrm{C}$, May $13.4{ }^{\circ} \mathrm{C}$, June $16.6{ }^{\circ} \mathrm{C}$, and July $18.9^{\circ} \mathrm{C}$, average air humidity- $75.9 \%$, length of daytime-from $12 \mathrm{~h} 57 \mathrm{~min}$ to $16 \mathrm{~h}$ $31 \mathrm{~min})$.

\subsection{Methods of Plant and Soil Analyses}

The maize was harvested in the middle of panicle emergence (BBCH 55). Plant samples were collected during the corn harvest. The effect of potassium and nitrogen fertilizers on the trace element content in soil was published in an earlier paper [7]. Here, the trace element content in maize was analyzed. The sampled plant material was cut, dried, and ground, before wet-digesting in concentrated nitric acid $\left(\mathrm{HNO}_{3}\right.$ analytically pure) in Xpress Teflon ${ }^{\circledR}$ vessels in a MARS 6 microwave system manufactured by CEM Corporation (Matthews, NC, USA) [21]. The contents of trace elements (cadmium, lead, chromium, cobalt, nickel, zinc, copper, manganese, and iron) in the digested samples were determined via flame atomic absorption spectrometry (FAAS). The analysis was made using a Fluka standard solution with $\mathrm{Cd}, \mathrm{Pb}, \mathrm{Cr}, \mathrm{Co}, \mathrm{Ni}, \mathrm{Zn}, \mathrm{Cu}, \mathrm{Mn}$, and $\mathrm{Fe}$, as well as a certified reference material with an analyzed content of these trace elements (NCS ZC 73030). The results were then used to calculate the bioconcentration factor (BCF) using the following formula: $\mathrm{BCF}=$ content of element in maize/content of element in soil [22].

Before the start of the experiment, the soil was analyzed using the following methods: aerometric [23] and laser diffraction for particle size distribution; potentiometry for $\mathrm{pH}$ in $1 \mathrm{M} \mathrm{KCl} / \mathrm{L}$ [24]; Kjeldahl for total nitrogen [25]; Egner-Riehm for available forms of phosphorus and potassium [26]; Schachtschabel for available magnesium [27]; Bardsley and Lancaster's nephelometry for sulfur [28]. Total organic carbon (TOC) was analyzed via a Shimadzu TOC-L analyzer (Kyoto, Japan).

\subsection{Methods of Statistical Analyses}

ANOVA variance analysis (two-way), principal component analysis (PCA), and ANOVA for the calculated determination coefficient from Statistica 13 software [29] were used in statistical calculations of results obtained in experiment. The levels $* \leq 0.05$ and ${ }^{* *} p \leq 0.01$ were applied for calculation of significance of differences between mineral doses. Two post hoc tests, least squares deviation (LSD) and Tukey's HSD (honestly significant difference), were used. 


\section{Results}

The contents of trace elements in the aerial parts of maize were strongly correlated with potassium and nitrogen fertilization (Tables 1 and 2). Most of the trace elements showed a stronger response to potassium fertilization in the high-nitrogen series (170 $\mathrm{mg}$ per $\mathrm{kg}$ of soil) than in low-nitrogen objects (130 mg per $\mathrm{kg}$ of soil).

Potassium fertilization led to increased levels of all trace elements in maize in the low-nitrogen objects, with a close-to-linear growth in trace element accumulation recorded for cadmium, lead, nickel, zinc, and manganese in the aerial parts of plants (Tables 1 and 2). The highest dose of potassium ( $240 \mathrm{mg}$ per $\mathrm{kg}$ of soil) resulted in increases of these elements in maize by $31 \%(r=0.988), 39 \%(r=0.921), 48 \%(r=0.988), 92 \%(r=0.910)$, and $149 \%$ $(r=0.970)$, respectively, compared with the control object (without potassium fertilization). Other trace elements also showed increased accumulation in maize at the two lower potassium doses (140 and $190 \mathrm{mg}$ per $\mathrm{kg}$ of soil). Under the effect of $140 \mathrm{mg}$ of potassium per $\mathrm{kg}$ of soil, the chromium level increased by $49 \%(r=0.569)$. In turn, at $190 \mathrm{mg}$ potassium per $\mathrm{kg}$ of soil, the accumulation of copper, cobalt, and iron in maize increased by $48 \%$ $(r=0.682), 76 \%(r=0.824)$, and $90 \%(r=0.588)$, respectively. However, the highest dose of potassium $(240 \mathrm{mg} / \mathrm{kg}$ of soil) produced lower levels of these elements in the aerial parts of plants. No statistically proven correlations were shown between potassium fertilization and lead/chromium content.

Table 1. Cadmium, lead, chromium, and cobalt content in maize-Zea mays L. (mg per kg dry matter (DM)).

\begin{tabular}{|c|c|c|c|c|}
\hline \multirow{2}{*}{ Potassium Dose (mg per kg of Soil) } & \multicolumn{4}{|c|}{ Trace Elements } \\
\hline & $\mathrm{Cd}$ & $\mathbf{P b}$ & $\mathrm{Cr}$ & Co \\
\hline \multicolumn{5}{|c|}{ Low-Nitrogen Dose (130 mg per kg of soil) } \\
\hline 0 & $0.036 \mathrm{~d}$ & $0.163 \mathrm{a}$ & $0.167 \mathrm{a}$ & $0.085 \mathrm{~d}$ \\
\hline 140 & $0.043 \mathrm{bc}$ & 0.177 a & 0.248 a & $0.113 b$ \\
\hline 190 & $0.044 \mathrm{c}$ & $0.202 \mathrm{a}$ & $0.241 \mathrm{a}$ & $0.150 \mathrm{a}$ \\
\hline 240 & $0.047 \mathrm{c}$ & 0.227 a & $0.201 \mathrm{a}$ & $0.125 \mathrm{~b}$ \\
\hline Average & 0.042 & 0.192 & 0.214 & 0.118 \\
\hline$r$ & $0.988^{* *}$ & $0.921 * *$ & $0.569 *$ & $0.824 * *$ \\
\hline \multicolumn{5}{|c|}{ High-Nitrogen Dose (170 mg per kg of soil) } \\
\hline 0 & $0.019 \mathrm{a}$ & $0.113 \mathrm{a}$ & $0.243 \mathrm{a}$ & $0.042 \mathrm{c}$ \\
\hline 140 & $0.035 \mathrm{e}$ & $0.113 \mathrm{a}$ & $0.231 \mathrm{a}$ & 0.059 ce \\
\hline 190 & $0.035 \mathrm{e}$ & $0.115 \mathrm{a}$ & $0.216 \mathrm{a}$ & $0.075 \mathrm{de}$ \\
\hline 240 & $0.037 \mathrm{bd}$ & $0.143 \mathrm{a}$ & $0.164 \mathrm{a}$ & $0.072 \mathrm{de}$ \\
\hline Average & 0.031 & 0.121 & 0.213 & 0.062 \\
\hline$r$ & $0.953^{* *}$ & $0.671 *$ & $-0.834^{* *}$ & $0.952^{* *}$ \\
\hline \multicolumn{5}{|c|}{ Average } \\
\hline 0 & 0.027 & 0.138 & 0.205 & 0.063 \\
\hline 140 & 0.039 & 0.145 & 0.239 & 0.086 \\
\hline 190 & 0.039 & 0.159 & 0.228 & 0.113 \\
\hline 240 & 0.042 & 0.185 & 0.183 & 0.098 \\
\hline Average & 0.037 & 0.156 & 0.214 & 0.090 \\
\hline$r$ & $0.974^{* *}$ & $0.864^{* *}$ & -0.147 & $0.879^{* *}$ \\
\hline \multicolumn{5}{|l|}{ LSD for } \\
\hline Nitrogen dose & $0.001^{* *}$ & n.s. & n.s. & $0.005^{* *}$ \\
\hline Potassium dose & $0.002^{* *}$ & n.s. & n.s. & $0.007^{* *}$ \\
\hline Interaction & $0.003^{* *}$ & n.s. & n.s. & $0.010^{* *}$ \\
\hline
\end{tabular}

LSD (least squares deviation); significant for ${ }^{* *} p \leq 0.01,{ }^{*} p \leq 0.05$; n.s., nonsignificant; $r$-correlation coefficient; DM-dry matter. Homogeneous groups denoted with letters a-e were calculated for the interaction between potassium dose and nitrogen dose. 
Table 2. Nickel, zinc, copper, manganese, and iron content in maize-Zea mays L. (mg per kg DM).

\begin{tabular}{|c|c|c|c|c|c|}
\hline \multirow{2}{*}{ Potassium Dose (mg per kg of Soil) } & \multicolumn{5}{|c|}{ Trace Elements } \\
\hline & $\mathbf{N i}$ & Zn & $\mathrm{Cu}$ & Mn & $\mathbf{F e}$ \\
\hline \multicolumn{6}{|c|}{ Low-Nitrogen Dose (130 mg per kg of soil) } \\
\hline 0 & $0.285 \mathrm{ab}$ & $6.80 \mathrm{~b}$ & $0.324 \mathrm{a}$ & $9.06 \mathrm{~b}$ & $15.29 \mathrm{~b}$ \\
\hline 140 & $0.381 \mathrm{ab}$ & $8.11 \mathrm{~b}$ & 0.388 a & $16.92 \mathrm{de}$ & $21.30 \mathrm{bd}$ \\
\hline 190 & $0.410 \mathrm{~b}$ & $10.30 \mathrm{ab}$ & $0.479 \mathrm{a}$ & $16.95 \mathrm{de}$ & $29.06 \mathrm{~cd}$ \\
\hline 240 & $0.421 \mathrm{~b}$ & $13.06 \mathrm{a}$ & 0.389 a & 22.60 ce & $19.51 \mathrm{bd}$ \\
\hline Average & 0.374 & 9.57 & 0.395 & 16.38 & 21.29 \\
\hline$r$ & $0.988^{* *}$ & $0.910 * *$ & $0.682 *$ & $0.970^{* *}$ & $0.588 *$ \\
\hline \multicolumn{6}{|c|}{ High-Nitrogen Dose (170 mg per kg of soil) } \\
\hline 0 & $0.216 \mathrm{a}$ & $7.01 \mathrm{~b}$ & $0.466 \mathrm{a}$ & $11.83 \mathrm{bd}$ & $28.52 \mathrm{~cd}$ \\
\hline 140 & $0.279 \mathrm{ab}$ & $9.02 \mathrm{ab}$ & $0.492 \mathrm{a}$ & $17.94 \mathrm{ce}$ & $35.98 \mathrm{ac}$ \\
\hline 190 & $0.290 \mathrm{ab}$ & $10.84 \mathrm{ab}$ & 0.389 a & 23.78 ac & $34.62 \mathrm{ac}$ \\
\hline 240 & $0.302 \mathrm{ab}$ & 12.18 a & $0.233 \mathrm{a}$ & 28.98 a & $42.25 \mathrm{a}$ \\
\hline Average & 0.272 & 9.76 & 0.395 & 20.63 & 35.34 \\
\hline$r$ & $0.987^{* *}$ & $0.977^{* *}$ & $-0.732 * *$ & $0.969^{* *}$ & $0.921^{* *}$ \\
\hline \multicolumn{6}{|c|}{ Average } \\
\hline 0 & 0.250 & 6.90 & 0.395 & 10.45 & 21.90 \\
\hline 140 & 0.330 & 8.56 & 0.440 & 17.43 & 28.64 \\
\hline 190 & 0.350 & 10.57 & 0.434 & 20.36 & 31.84 \\
\hline 240 & 0.361 & 12.62 & 0.311 & 25.79 & 30.88 \\
\hline Average & 0.323 & 9.66 & 0.395 & 18.51 & 28.31 \\
\hline$r$ & $0.988^{* *}$ & $0.947^{* *}$ & -0.351 & $0.983^{* *}$ & $0.957^{* *}$ \\
\hline \multicolumn{6}{|l|}{ LSD for: } \\
\hline Nitrogen dose & $0.049 * *$ & n.s. & n.s. & $1.29 * *$ & $2.79^{* *}$ \\
\hline Potassium dose & $0.069 * *$ & $1.25^{* *}$ & $0.119 * *$ & $1.82 * *$ & $3.95 * *$ \\
\hline Interaction & n.s. & n.s. & n.s. & $2.58^{* *}$ & $5.58^{* *}$ \\
\hline
\end{tabular}

LSD (least squares deviation); significant for ${ }^{* *} p \leq 0.01{ }^{*} p \leq 0.05$; n.s., nonsignificant; $r$ —correlation coefficient; DM-dry matter. Homogeneous groups denoted with letters a-e were calculated for the interaction between potassium dose and nitrogen dose.

Applying additional nitrogen into the soil (170 mg per kg of soil) altered the relatively tangible effect of potassium fertilizers on trace element content in maize (Tables 1 and 2). In contrast, potassium fertilization was linearly correlated with levels of lead, nickel, iron, zinc, cadmium, manganese, and chromium in maize; however, it caused an increase in levels of the first six and a decrease in level of the last one. The exact changes were, respectively, $\mathrm{Pb}$ $+27 \%(r=0.671), \mathrm{Ni}+40 \%(r=0.987), \mathrm{Fe}+48 \%(r=0.921), \mathrm{Zn}+74 \%(r=0.977), \mathrm{Cd}+95 \%$ $(r=0.953), \mathrm{Mn}+145 \%(r=0.969)$, and $\mathrm{Cr}-33 \%(r=-0.834)$. The lowest dose of potassium also led to a slight, $6 \%$ increase in copper level $(r=-0.732)$, whereas the second-lowest dose increased cobalt level by $79 \%(r=0.952)$ compared to the control object (without potassium fertilization). The higher potassium doses reduced the content of these elements, copper in particular.

Nitrogen fertilization had no unequivocal effect on the trace element content of maize (Tables 1 and 2). Nitrogen amendment increased the accumulation of manganese by $26 \%$ and of iron by $66 \%$ on average, while decreasing the accumulation of cadmium, nickel, lead, and cobalt by $26 \%, 27 \%, 37 \%$, and $47 \%$, respectively, compared with the low-nitrogen series. However, the changes in lead content were statistically insignificant.

A statistical analysis of the results (PCA, Pearson linear correlation coefficient) demonstrated the cumulative impact of both fertilizers (potassium and nitrogen) on the content of trace elements in maize, as illustrated by the vector variables in Figure 1 and coefficients of correlation in Table 3. The total correlation of the cadmium/nickel/lead/cobalt dataset was $46.74 \%$ and that of the "other trace elements" (manganese/zinc/iron/copper/chromium) 
was $29.82 \%$. The vectors of most trace elements were similar in length, with only those of iron, copper, and chromium being shorter, suggesting their lesser contribution to the variability. The analysis showed strong positive correlations between nickel/cadmium and lead/cobalt, between cobalt and lead, between nickel and cadmium, and between manganese and zinc; as well as weaker correlations between copper and chromium and between manganese and iron. Negative correlations between some of the elements were much weaker and insignificant.

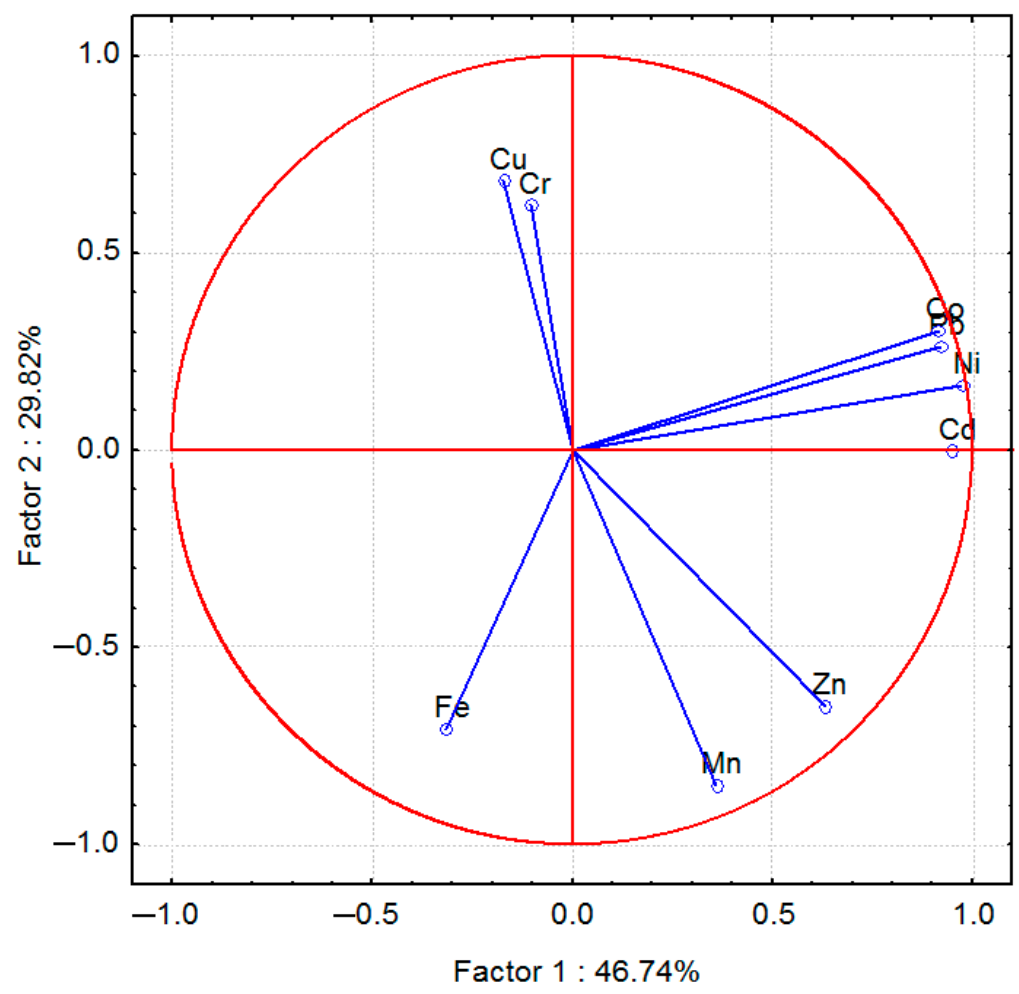

Figure 1. Trace element content in maize (Zea mays L.) calculated using the principal component analysis (PCA) method. Vectors represent elements ( $\mathrm{Cd}, \mathrm{Pb}, \mathrm{Cr}, \mathrm{Co}, \mathrm{Ni}, \mathrm{Zn}, \mathrm{Cu}, \mathrm{Mn}$, and $\mathrm{Fe}$ ) as PCA results.

Table 3. Coefficients of correlation $(r)$ between trace elements content in maize-Zea mays L.

\begin{tabular}{|c|c|c|c|c|c|c|c|c|}
\hline Trace Element & $\mathrm{Cd}$ & $\mathrm{Pb}$ & $\mathrm{Cr}$ & Co & $\mathbf{N i}$ & Zn & $\mathrm{Cu}$ & Mn \\
\hline $\mathrm{Pb}$ & 0.484 * & & & & & & & \\
\hline $\mathrm{Cr}$ & -0.075 & -0.035 & & & & & & \\
\hline Co & $0.851^{* *}$ & $0.601^{* *}$ & 0.127 & & & & & \\
\hline $\mathrm{Ni}$ & $0.843^{* *}$ & $0.501^{* *}$ & 0.006 & $0.860^{* *}$ & & & & \\
\hline $\mathrm{Zn}$ & $0.521^{* *}$ & 0.192 & -0.247 & 0.349 & $0.457^{*}$ & & & \\
\hline $\mathrm{Cu}$ & -0.100 & -0.087 & $0.762 * *$ & 0.068 & -0.107 & -0.295 & & \\
\hline Mn & 0.335 & 0.057 & -0.218 & 0.073 & 0.244 & $0.868^{* *}$ & -0.396 & \\
\hline $\mathrm{Fe}$ & -0.278 & -0.343 & -0.047 & -0.389 & -0.281 & 0.344 & -0.088 & $0.629 * *$ \\
\hline
\end{tabular}

Significant for $* * p \leq 0.01 * p \leq 0.05$.

The distribution of results in Figure 2 shows that the cumulative impact of potassium fertilization, especially at higher doses (190-240 mg per kg of soil), was ultimately stronger than that of nitrogen fertilization, especially in the high-nitrogen series. 


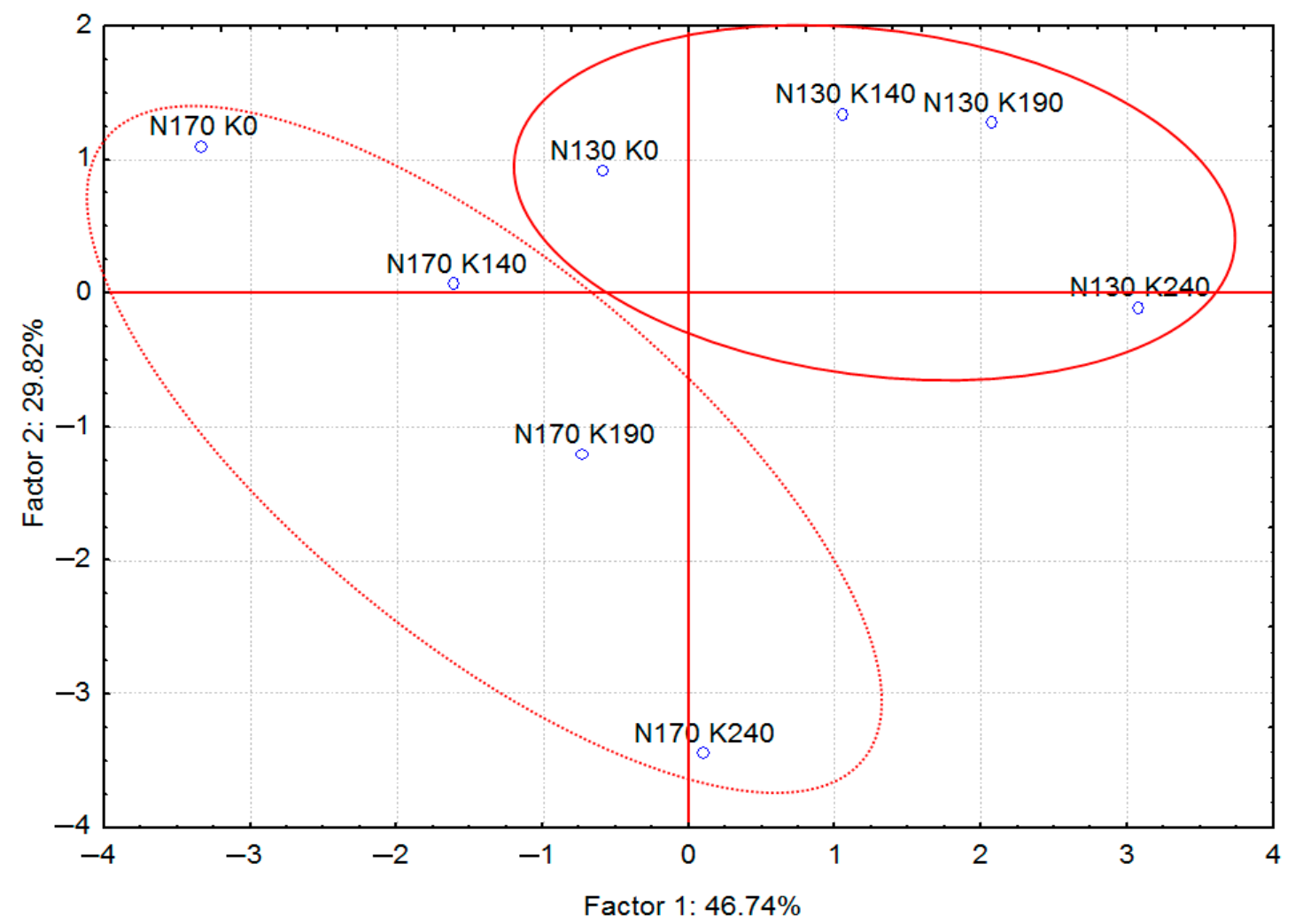

Figure 2. Impact of fertilization doses on trace element content in maize (Zea mays L.) calculated using the PCA method. Points show the content of all trace elements in plants ( N 130 - $130 \mathrm{mg}$ N per kg, N 170—170 mg N per kg; K0—0 mg K per kg (control), K140—140 mg K per kg, K190—190 mg K per kg, K240—240 mg K per kg of soil).

The observed variance ratio (calculated on the basis of coefficient $\eta 2$, using the ANOVA method) showed no significant advantage of either potassium or nitrogen fertilization on trace element content in maize across both series and all pots (Figure 3). The distribution of the effect of potassium fertilization was highest for copper- $28.7 \%$, chromium-31.0\%, manganese $-82.2 \%$, and zinc- $91.7 \%$, while it was also quite high for cobalt-28.0\%, nickel-34.1\%, and cadmium-46.8\%. It should be noted, however, that the impact of nitrogen fertilization was stronger compared to potassium fertilization with regard to the levels of lead $-31.8 \%$, nickel- $47.5 \%$, cadmium $-48.3 \%$, iron $-64.4 \%$, and cobalt- $68.2 \%$. The impact of both fertilizers on the cadmium content of maize was similar.

Potassium and nitrogen fertilization affected the iron-zinc and iron-manganese ratios in maize (Figure 4). In low-nitrogen objects (130 $\mathrm{mg}$ per $\mathrm{kg}$ of soil), potassium fertilization at doses up to $190 \mathrm{mg}$ per $\mathrm{kg}$ of soil resulted in higher Fe:Zn ratios, whereas the highest dose of potassium ( $240 \mathrm{mg}$ per $\mathrm{kg}$ of soil) produced lower ratios. Potassium fertilization lowered the Fe:Zn ratio in maize in the high-nitrogen series (170 mg per $\mathrm{kg}$ of soil). In turn, the Fe:Mn ratio was lowered by potassium fertilization in both series concurrently fertilized with nitrogen. The application of nitrogen raised the ratios of Fe:Zn and Fe:Mn in maize, especially in the control pot (with no added potassium) and in the pots with the lowest potassium dose (140 $\mathrm{mg}$ per $\mathrm{kg}$ of soil). 


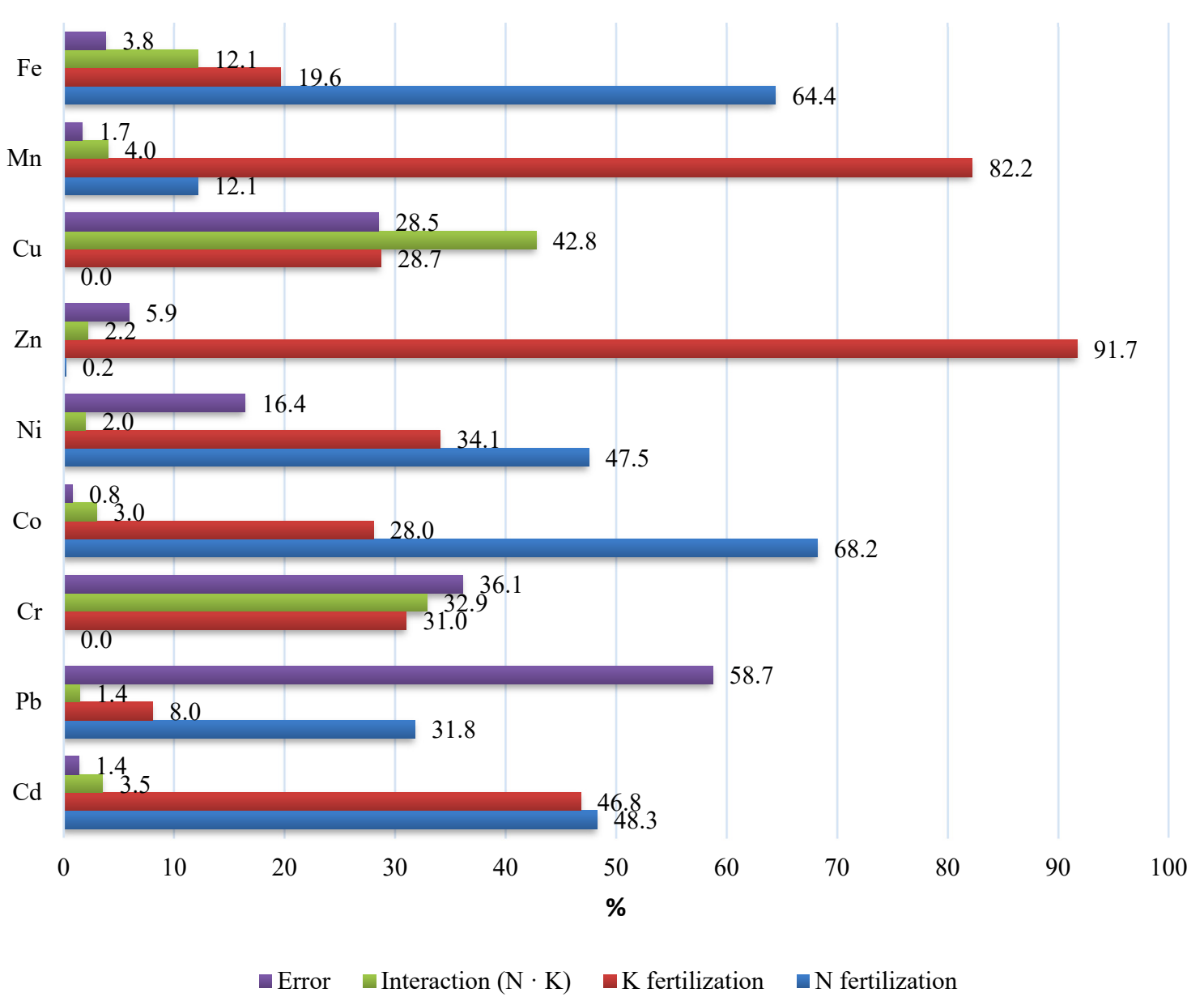

Figure 3. Relative effect of factors on trace element content in maize-Zea mays L. (as a percentage).
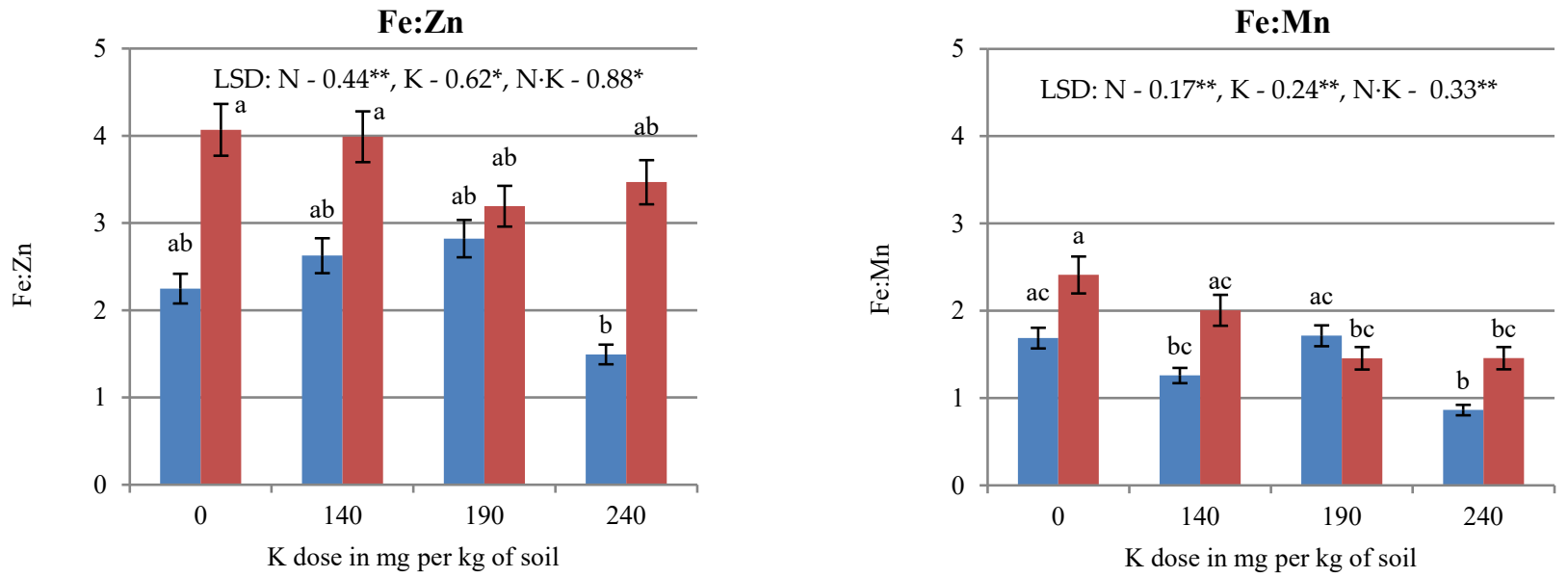

- 130 mg N per $\mathrm{kg}$ of soil $\quad$ - $170 \mathrm{mg} \mathrm{N}$ per $\mathrm{kg}$ of soil LSD significant for: ${ }^{* *} p \leq 0.01,{ }^{*} p \leq 0.05$

Figure 4. Fe:Zn and Fe:Mn ratios in the aerial parts of maize (Zea mays L.). Homogeneous groups denoted with letters a-c were calculated for the interaction between potassium dose and nitrogen dose.

Potassium and nitrogen fertilization significantly affected values of bioconcentration factors for trace elements in the aerial parts of maize (Figures 5 and 6). 

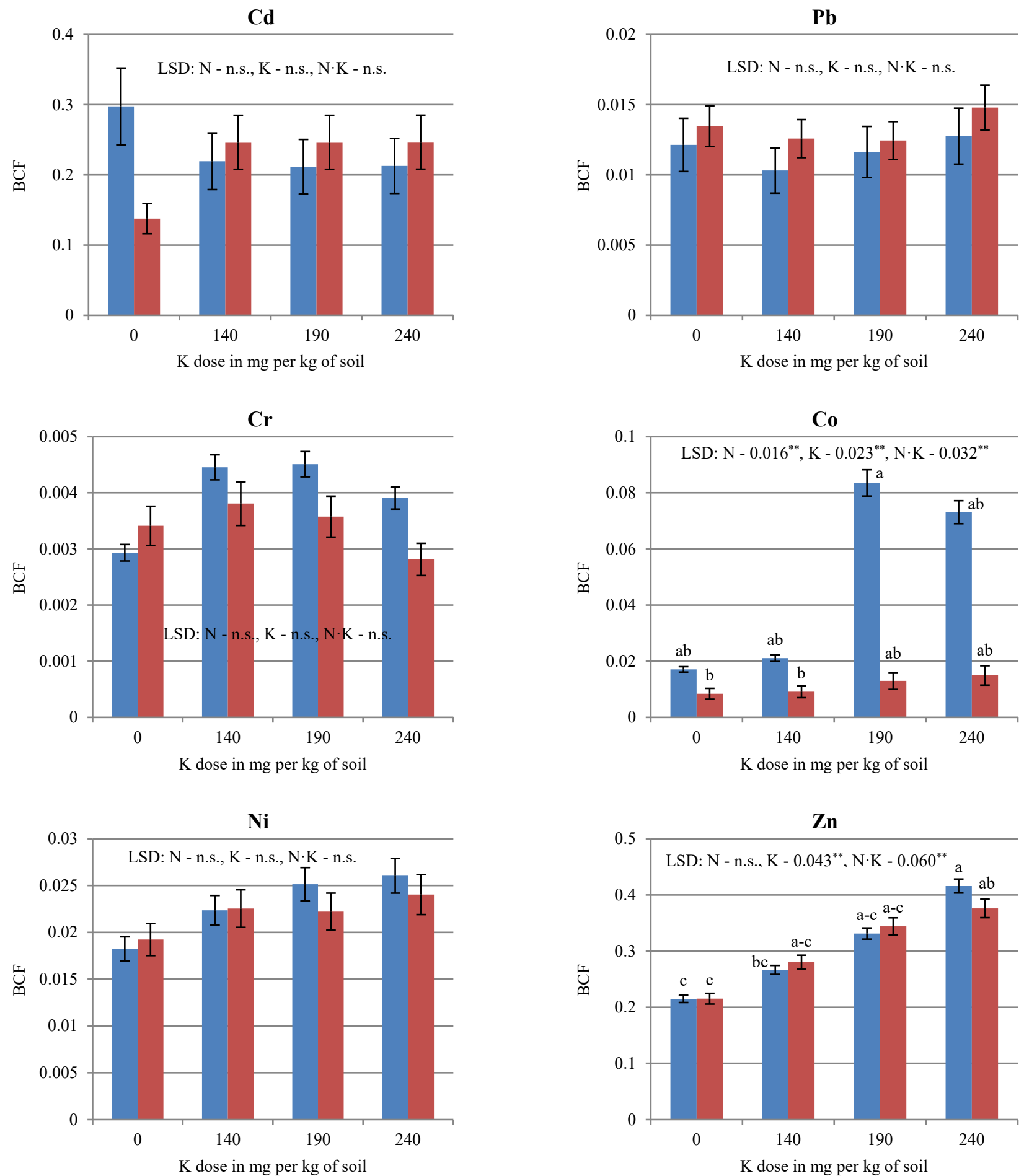

- $130 \mathrm{mg} \mathrm{N}$ per kg of soil $\quad 170 \mathrm{mg} \mathrm{N}$ per $\mathrm{kg}$ of soil LSD significant for: ${ }^{* *} p \leq 0.01$, n.s. non-significant

Figure 5. Bioconcentration factor (BCF) of cadmium, lead, chromium, cobalt, nickel, and zinc in the aerial parts of maize (Zea mays L.). Homogeneous groups denoted with letters a-c were calculated for the interaction between potassium dose and nitrogen dose. 

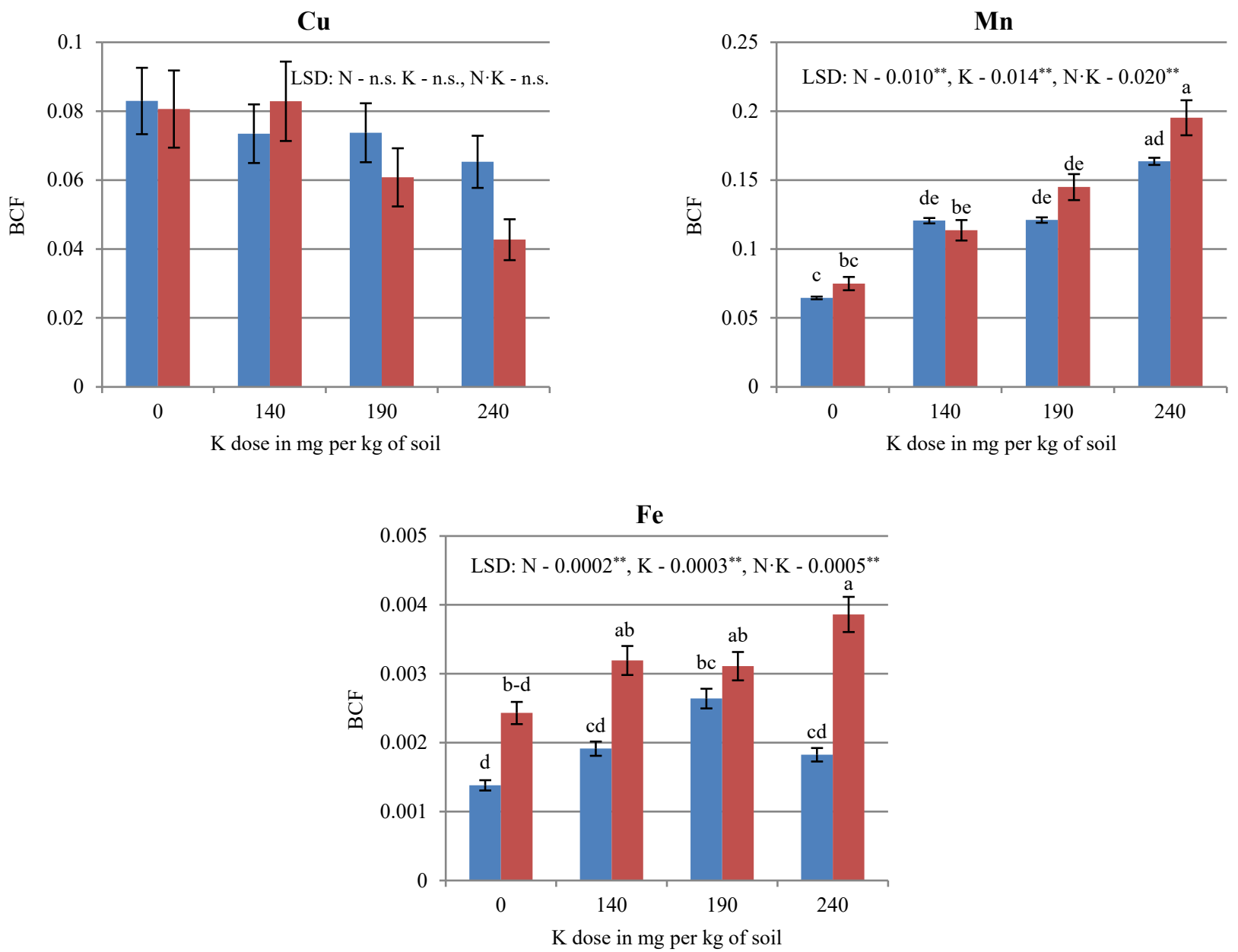

- $130 \mathrm{mg} \mathrm{N}$ per $\mathrm{kg}$ of soil $\quad 170 \mathrm{mg} \mathrm{N}$ per $\mathrm{kg}$ of soil LSD significant for: ${ }^{* *} p \leq 0.01$, n.s. non-significant

Figure 6. Bioconcentration factor (BCF) of copper, manganese, and iron in the aerial parts of maize (Zea mays L.). Homogeneous groups denoted with letters a-e were calculated for the interaction between potassium dose and nitrogen dose.

In low-nitrogen objects, potassium fertilization contributed to higher bioconcentration factors determined for nickel $(r=0.991)$, zinc $(r=0.929)$, and especially manganese $(r=0.968)$ in the aerial parts of maize against control. The BCFs computed for cadmium $(r=-0.942)$ and copper $(r=-0.954)$ were lower than in the control. The BCFs also increased for chromium $(r=0.732)$, cobalt $(r=0.804)$, and iron $(r=0.629)$, but only at doses up to $190 \mathrm{~kg} \mathrm{~K}$ per $\mathrm{kg}$ of soil, while higher doses produced lower BCF values. In high-nitrogen objects (170 mg per $\mathrm{kg}$ of soil), changes in trace elements BCFs in the aerial parts of maize were more consistent than in the low-nitrogen series ( $130 \mathrm{mg}$ per $\mathrm{kg}$ of soil). Potassium fertilizers systematically increased the bioconcentration factors for cadmium $(r=0.919)$, cobalt $(r=0.881)$, nickel $(r=0.964)$, zinc $(r=0.979)$, iron $(r=0.936)$, and especially manganese $(r=0.948)$. The lowest potassium dose produced a slight increase in chromium and copper $\mathrm{BCFs}$, with higher doses leading to a decrease in their BCFs $(r=-0.393$ and $r=-0.794$, respectively). Compared with potassium, nitrogen fertilization produced less extensive changes in bioconcentration factors for trace elements in the aerial parts of maize. Increasing the dose of nitrogen to $170 \mathrm{mg}$ per $\mathrm{kg}$ of soil increased the BCF values of manganese, lead, and iron, and decreased those of nickel, copper, chromium, and cobalt. Nitrogen had the strongest impact on iron and cobalt BCFs in the aerial parts of maize. 


\section{Discussion}

In addition to their main constituents, mineral fertilizers also contain trace elements, mainly cadmium and lead [18], as well as nickel and zinc [30]. To properly grow and develop, plants require soil macro- and microelements at levels sufficient to satisfy their nutritional needs. Some soils are deficient in trace elements, e.g., in copper, nickel, zinc, manganese, molybdenum, and cobalt, namely, elements essential for plant growth and high-quality crops [31]. Nutrient deficiencies must, therefore, be covered through soil or foliar fertilization. Even base (single- or two-component) fertilizers, e.g., nitrogen and potassium fertilizers, contain certain amounts of trace elements as ballast materials. Mineral fertilizers used in intensive farming can significantly increase trace element levels in soil and plants [32].

In a study by Miner et al. [19], nitrogen fertilization increased certain trace element levels in the aerial parts of maize, particularly those of copper and manganese in the aerial parts and iron in the kernels. Only the zinc content decreased in all parts of the plant. The trace element content of maize and other plant species strongly correlates with the accumulation of these elements in soil, especially in plant-available forms [4]. A study by Kacálková et al. [33] showed that only a small fraction of these elements was available for plants-less than $1 \% \mathrm{Cr}, 1.3 \% \mathrm{~Pb}, 6 \% \mathrm{Ni}$, and $14 \% \mathrm{Cd}$. In an experiment by Ali et al. [34], nitrogen fertilizers applied to the soil increased iron uptake by maize, resulting in a significant increase in bioavailable iron species and a decrease in soil $\mathrm{pH}$. These relationships are largely corroborated by the present study because nitrogen fertilization increased manganese and iron levels in maize.

In a study by Losak et al. [35], nitrogen fertilizers increased levels of iron and zinc in maize. It should be noted, however, that the iron-zinc and iron-manganese ratios in maize were still optimal, as iron did not impair the uptake of these trace elements by plants. Similar dependencies in levels of iron and to a smaller degree of zinc (objects with control, 140 and $190 \mathrm{mg} \mathrm{K}$ per $\mathrm{kg}$ of soil only) in maize were observed in the present study. Martínez-Trujillo and Carreón-Abud [36] demonstrated increased chromium levels after applying nitrogen. This relationship was not confirmed in the present study. Higher chromium accumulation in maize was found only in plants not fertilized with potassium in objects with a second nitrogen dose. In a study by Li et al. [37], fertilization with nitrogen at $200 \mathrm{~kg}$ per ha caused a large $(65 \%$ on average) increase in the cadmium content of the plants, albeit still within the acceptable limits. Additionally, cadmium levels in plants were shown to significantly vary depending on environmental conditions. Wångstrand et al. [38] noted similar associations. The reverse effect was observed in the present study. A study by Losak et al. [35] found correlations between levels of $\mathrm{Zn}$ and Mn and levels of Fe and Mn in nitrogen-fertilized maize, similar to the present study. The nitrogen fertilizers increased the iron-zinc and iron-manganese ratios in maize in the present study and in the Losak et al. study [35].

According to Carbonell et al. [39], NPK fertilizers can increase the cadmium and nickel contents of soil and maize, with the increases being the highest for roots and the lowest for cobs and kernels. The root system functions as a barrier to many trace elements-chromium, nickel, lead, and mercury in particular-and limits the metals translocation to plants the aerial parts. A study by Pogrzeba et al. [40] showed that NPK fertilization promoted the element uptake (especially zinc) by plants. Nitrogen fertilization and increasing doses of potassium also increased the zinc content in the test plant in the present study.

A study by Brodowska et al. [41] suggested that potassium fertilization positively correlated with iron and manganese contents of plants. Similar associations were found between nitrogen fertilization and plant Fe/Mn. The same relations between potassium and nitrogen fertilization and iron and manganese contents in maize were observed in the present study. Potassium fertilization may play a particularly vital role in this regard, as potassium is one of the elements essential for plant water balance and uptake of other elements, including heavy metals [42]. According to Gaj et al. [43], mineral fertilization boosts copper and manganese levels in maize. This relationship was confirmed only in 
the case of manganese in the present study. Extended (10 year) cessation of potassium application inhibited trace element uptake by maize relative to K-fertilized plots. Similar associations were found for phosphorus fertilization. On average, more than $50 \%$ of the copper accumulated in the kernels, whereas 50-64\% of the manganese accumulated in the leaves [43]. In our study, no potassium fertilizer also resulted in lower contents of chromium, cobalt, nickel, zinc, manganese, and iron in the maize biomass.

In an experiment by Wang et al. [44], the accumulation of trace elements in maize kernels rose as follows: $\mathrm{Pb}<\mathrm{Cr}<\mathrm{Zn}<\mathrm{As}<\mathrm{Cu}<\mathrm{Cd}<\mathrm{Hg}$. According to Gaj et al. [43], larger deficiencies of trace elements were found in the earlier stages of growth compared to fully mature maize.

Aladesanmi et al. [4] reported the following values of trace elements bioconcentration factors (BCFs) in maize: cadmium 0-0.95, lead 0-1.20, chromium 0-1.89, copper 0.011-0.99, and zinc $0.03-0.99$. The high mobility of cadmium and zinc resulted in the highest values of their bioconcentration factors in maize in the present study. An experiment by Wang et al. [44] showed lower BCF values of trace elements in maize kernels: chromium-0.000665, lead-0.0044, cadmium-0.054, copper-0.13, and zinc-0.19. These results suggest that zinc, cadmium, and copper accumulate more readily than chromium or lead, which is most likely the case in other plants as well. The BCFs determined for trace elements in maize in present study were higher than in the experiment by Wang et al. [44]. In turn, Zhuang et al. [45] demonstrated higher bioconcentration factors for zinc and cadmium compared with lead and copper, which is in line with the present study. Molina et al. [46] reported that cadmium and zinc were more mobile from soil to plant compared with copper and arsenic. Martínez-Trujillo and Carreón-Abud [36] also found higher BCFs and translocation factors for chromium after applying nitrogen. NPK fertilization increased the bioconcentration factor and decreased the translocation factor for cadmium in maize in a Wang et al. study [47]. Potassium fertilization increased the bioconcentration factors of most trace elements in maize in the authors' own research. The effect of nitrogen fertilization on the BCF of trace elements in maize was less regular, positive for cadmium and lead, and negative for chromium and cobalt.

The research hypotheses were confirmed by the experiment. However, it should be emphasized that, in the present study, relatively smaller increases in the content of trace elements in maize were observed after the application of a higher dose of nitrogen, in relation to literature data. This is probably related to the urea-ammonium nitrate solution used in the experiment. Urea-ammonium nitrate solution is characterized by higher purity compared to solid nitrogen fertilizers. The present studies, therefore, highlight the benefits of using liquid forms of mineral fertilizers, which in most cases are characterized by a higher purity compared to solid mineral fertilizers.

\section{Conclusions}

Potassium and nitrogen fertilization was found to have a significant effect on the trace element content of maize.

Application of potassium fertilizer increased the accumulation of the examined elements in maize. Higher doses of potassium fertilizer led to a linear increase in the contents of cadmium, lead, nickel, zinc, and manganese, and to lower Fe:Zn and Fe:Mn ratios in maize. In turn, cobalt level increased in maize upon the lower doses and decreased upon the higher doses of potassium. Potassium fertilization led to a higher bioconcentration (higher BCFs) of most of the trace elements in the aerial parts of maize.

Nitrogen fertilization led to increased contents of manganese and iron and decreased contents of cadmium, lead, nickel, and cobalt, while also boosting Fe:Zn and Fe:Mn ratios in maize. Compared with potassium, nitrogen fertilization produced less consistent changes in bioconcentration factors for trace elements in the aerial parts of maize. 
Author Contributions: Conceptualization, M.S.B.; methodology, M.S.B.; analysis, M.W.; writingreview and editing, M.W. and M.S.B.; M.S.B., corresponding author. All authors contributed significantly to the discussion of the results and the preparation of the manuscript. All authors have read and agreed to the published version of the manuscript.

Funding: This study was supported by the Ministry of Science and Higher Education funds for statutory activity. The project was financially supported by the Minister of Science and Higher Education in the range of the program entitled "Regional Initiative of Excellence" for the years 2019-2022, Project No. 010/RID/2018/19; amount of funding, 12,000,000 PLN.

Institutional Review Board Statement: Not applicable.

Informed Consent Statement: Not applicable.

Data Availability Statement: Data are available by contacting the authors.

Conflicts of Interest: The authors declare no conflict of interest. The funders had no role in the design of the study; in the collection, analyses, or interpretation of data; in the writing of the manuscript, or in the decision to publish the results.

\section{References}

1. Njira, K.O.W.; Nabwami, J. A review of effects of nutrient elements on crop quality. Afr. J. Food Agric. Nutr. Dev. 2015, 15, 9777-9793. Available online: https:/ /www.ajol.info/index.php/ajfand/article/view/113419/103140 (accessed on 14 October 2020).

2. Kosiorek, M.; Wyszkowski, M. Remediation of cobalt-contaminated soil using manure, clay, charcoal, zeolite, calcium oxide, main crop (Hordeum vulgare L.), and after-crop (Synapis alba L.). Minerals 2020, 10, 429. [CrossRef]

3. Nagajyoti, P.C.; Lee, K.D.; Sreekanth, T.V. Heavy metals, occurrence and toxicity for plants: A review. Environ. Chem. Lett. 2010, 8 , 199-216. [CrossRef]

4. Aladesanmi, O.T.; Oroboade, J.G.; Osisiogu, C.P.; Osewole, A.O. Bioaccumulation factor of selected heavy metals in Zea mays. J. Health Pollut. 2019, 9, 191207. Available online: https: / / www.journalhealthpollution.org/doi/pdf/10.5696/2156-9614-9.24.191207 (accessed on 19 October 2020). [PubMed]

5. Wang, Y.; Qiao, M.; Liu, Y.; Zhu, Y. Health risk assessment of heavy metals in soils and vegetables from wastewater irrigated area, Beijing-Tianjin city cluster, China. J. Environ. Sci. 2012, 24, 690-698. [CrossRef]

6. Osakwe, S.A.; Akpoveta, O.V.; Okoh, B.E.; Ize-Iyamu, O.K. Chemical forms of heavy metals in soils around municipal waste dumpsites in Asaba Metropolis, Delta State, Nigeria. Chem. Spec. Bioavailab. 2012, 24, 23-30. [CrossRef]

7. Wyszkowski, M.; Brodowska, M.S. Content of trace elements in soil fertilized with potassium and nitrogen. Agriculture 2020, 10, 398. [CrossRef]

8. Regulation (EC) No $2003 / 2003$ of the European Parliament and of the Council of 13 October 2003 relating to fertilizers. Off. J. L 2003, 304, 1-194.

9. Jordao, C.P.; Nascentes, C.C.; Cecon, P.R.; Fontes, R.L.; Pereira, J.L. Heavy metal availability in soil amended with composted urban solid wastes. Environ. Monit. Assess. 2006, 112, 309-326. [CrossRef]

10. Khan, S.; Cao, Q.; Zheng, Y.M.; Huang, Y.Z.; Zhu, Y.G. Health risks of heavy metals in contaminated soils and food crops irrigated with wastewater in Beijing, China. Environ. Pollut. 2008, 152, 686-692. [CrossRef]

11. Kabata-Pendias, A. Trace Elements in Soils and Plants, 4th ed.; CRC Press: Boca Raton, FL, USA, 2011; p. 403. Available online: http:/ / base.dnsgb.com.ua/ files/book/Agriculture/Soil/Trace-Elements-in-Soils-and-Plants.pdf (accessed on 2 October 2020).

12. Perilli, P.; Mitchell, L.G.; Grant, C.A.; Pisante, M. Cadmium concentration in durum wheat grain (Triticum turgidum) as influenced by nitrogen rate, seeding date and soil type. J. Sci. Food Agric. 2010, 90, 813-822. [CrossRef] [PubMed]

13. Cazzato, E.; Laudadio, V.; Tufarelli, V. Effects of harvest period, nitrogen fertilization and mycorrhizal fungus inoculation on triticale ( $\times$ Triticosecale Wittmack) forage yield and quality. Renew. Agric. Food Syst. 2012, 27, 278-286. [CrossRef]

14. Strachel, R.; Wyszkowska, J.; Baćmaga, M. The effect of nitrogen on the microbiological and biochemical properties of zinccontaminated soil. J. Environ. Eng. Landsc. Manag. 2017, 25, 13-22. [CrossRef]

15. Bai, L.-Y.; Zeng, X.-B.; Li, L.-F.; Pen, C.; Li, S.-H. Effects of land use on heavy metal accumulation in soils and sources analysis. Agric. Sci. China 2010, 9, 1650-1658. [CrossRef]

16. Liu, Y.; Wang, H.; Li, X.; Li, J. Heavy metal contamination of agricultural soils in Taiyuan, China. Pedosphere 2015, 25, 901-909. [CrossRef]

17. Czarnecki, S.; Düring, R.-A. Influence of long-term mineral fertilization on metal contents and properties of soil samples taken from different locations in Hesse, Germany. Soil 2015, 1, 23-33. [CrossRef]

18. Ajayi, S.O.; Odesanya, B.O.; Avwioroko, A.O.; Adebambo, G.S.; Okafor, B. Effects of long term fertilizer use on trace metal levels of soils in a farm settlement. J. Agricult. Res. Develop. 2012, 2, 44-51.

19. Miner, G.L.; Delgado, J.A.; Ippolito, J.A.; Barbarick, K.A.; Stewart, C.E.; Manter, D.K.; Del Grosso, S.J.; Halvorson, A.D.; Floyd, B.A.; D'Adamo, R. Influence of long-term nitrogen fertilization on crop and soil micronutrients in a no-till maize cropping system. Field Crops Res. 2018, 228, 170-182. [CrossRef] 
20. IUSS Working Group WRB. World Reference base for soil resources. In International Soil Classification System for Naming Soils and Creating Legends for Soil Maps; WRB: London, UK, 2014; Volume 106, p. 182.

21. Ostrowska, A.; Gawliński, S.; Szczubiałka, Z. Methods for Analysis and Evaluation of Soil and Plant Properties; IOŚ: Warszawa, Poland, 1991; pp. 1-334. (In Polish)

22. Ali, H.; Khan, E.; Sajad, M.A. Phytoremediation of heavy metals-concepts and applications. Chemosphere 2013, 91, 869-881. [CrossRef]

23. PN-R-04032. Soil and Mineral Materials—Sampling and Determination of Particle Size Distribution; Polish Committee for Standardization: Warszawa, Poland, 1998.

24. ISO 10390. Soil Quality—Determination of Ph; International Organization for Standardization: Geneva, Switzerland, 2005.

25. ISO 11261. Soil Quality—Determination of Total Nitrogen-Modified Kjeldahl Method; International Organization for Standardization: Geneva, Switzerland, 1995.

26. Egner, H.; Riehm, H.; Domingo, W.R. Untersuchun-gen über die chemische Bodenanalyse als Grundlage für die Beurteilung des Nährstoffzustandes der Böden. II. Chemische Extractionsmethoden zur Phospor- und Kaliumbestimmung. Ann. R. Agric. Coll. Sweden 1960, 26, 199-215.

27. Schlichting, E.; Blume, H.P.; Stahr, K. Bodenkundliches Praktikum; Pareys Studientexte 81; Blackwell Wissenschafts-Verlag: Berlin, Germany, 1995; p. 81.

28. Boratyński, K.; Grom, A.; Ziętecka, M. Research on the content of sulfur in soil. Part I. Rocz. Gleboz. 1975, 3, 121-139.

29. Dell Inc. Dell Statistica (Data Analysis Software System). Version 13. 2016. Available online: http://software.dell.com (accessed on 29 September 2020).

30. Leah, T. Effects of long-term application of fertilizers on the trace element content of soils. In Soil as World Heritage; Dent, D., Ed.; Springer: Dordrecht, The Netherlands, 2014. [CrossRef]

31. Lasat, M.M. Phytoextraction of metals from contaminated soil: A review of plant/soil/metal interaction and assessment of pertinent agronomic issues. J. Hazard. Subst. Res. 1999, 2, 1-25. [CrossRef]

32. Jones, L.H.P.; Jarvis, S.C. The fate of heavy metals. In The Chemistry of Soil Processes; Green, D.J., Hayes, M.H.B., Eds.; John Wiley and Sons: New York, NY, USA, 1981; p. 593.

33. Kacálková, L.; Tlustoš, P.; Száková, J. Chromium, nickel, cadmium, and lead accumulation in maize, sunflower, willow, and poplar. Pol. J. Environ. Stud. 2014, 23, 753-761.

34. Ali, N.S.; Hassan, W.F.; Janno, F.O. Soil iron and nitrogen availability and their uptake by maize plants as related to mineral and bio nitrogen fertilizers application. Agric. Biol. J. North Am. 2015, 6, 118-122. [CrossRef]

35. Losak, T.; Hlusek, J.; Martinec, J.; Jandak, J.; Szostkova, M.; Filipcik, R.; Manasek, J.; Prokes, K.; Peterka, J.; Varga, L.; et al. Nitrogen fertilization does not affect micronutrient uptake in grain maize (Zea mays L.). Acta Agric. Scand. B Soil Plant Sci. 2011, 61, 543-550. [CrossRef]

36. Martínez-Trujillo, M.; Carreón-Abud, Y. Effect of mineral nutrients on the uptake of Cr(VI) by maize plants. New Biotechnol. 2015, 32, 396-402. [CrossRef]

37. Li, X.; Ziadi, N.; Bélanger, G.; Cai, Z.; Xu, H. Cadmium accumulation in wheat grain as affected by mineral N fertilizer and soil characteristics. Can. J. Soil Sci. 2011, 91, 521-531. [CrossRef]

38. Wångstrand, H.; Eriksson, J.; Öborn, I. Cadmium concentration in winter wheat as affected by nitrogen fertilization. Eur. J. Agron. 2007, 26, 209-214. [CrossRef]

39. Carbonell, G.; de Imperial, R.M.; Torrijos, M.; Delgado, M.; Rodriguez, J.A. Effects of municipal solid waste compost and mineral fertilizer amendments on soil properties and heavy metals distribution in maize plants (Zea mays L.). Chemosphere 2011, 85, 1614-1623. [CrossRef]

40. Pogrzeba, M.; Rusinowski, S.Z.; Sitko, K.; Krzyżak, J.; Skalska, A.; Małkowski, E.; Ciszek, D.; Werle, S.; McCalmont, J.P.; Mos, M.; et al. Relationships between soil parameters and physiological status of Miscanthus $\times$ giganteus cultivated on soil contaminated with trace elements under NPK fertilisation vs. microbial inoculation. Environ. Pollut. 2017, 225, 163-174. [CrossRef]

41. Brodowska, M.S.; Kurzyna-Szklarek, M.; Filipek, T. Evaluation of the content of selected heavy metals in products of plant origin as a result of differentiated ratios of fertilizers. J. Elem. 2018, 23, 757-766. [CrossRef]

42. Wang, M.; Zheng, Q.; Shen, Q.; Guo, S. The critical role of potassium in plant stress response. Int. J. Mol. Sci. 2013, 14, 7370-7390. [CrossRef] [PubMed]

43. Gaj, R.; Bakk, K.; Budka, A. Copper and manganese acquisition in maize (Zea mays L) under different P and K fertilization. Biometr. Lett. 2016, 53, 1-36. [CrossRef]

44. Wang, S.; Wu, W.; Liu, F.; Liao, R.; Hu, Y. Accumulation of heavy metals in soil-crop systems: A review for wheat and corn. Environ. Sci. Pollut. Res. 2017, 24, 15209-15225. [CrossRef] [PubMed]

45. Zhuang, P.; McBride, M.B.; Xia, H.P.; Li, N.Y.; Li, Z. Health risk from heavy metals via consumption of food crops in the vicinity of Dabaoshan Mine, South China. Sci. Total Environ. 2009, 407, 1551-1561. [CrossRef]

46. Molina, M.; Escudey, M.; Chang, A.C.; Chen, W.; Arancibia-Miranda, N. Trace element uptake dynamics for maize (Zea mays L.) grown under field conditions. Plant Soil 2013, 370, 471-483. [CrossRef]

47. Wang, J.; Chen, X.; Chi, Y.; Chu, S.; Hayat, K.; Zhi, Y.; Hayat, S.; Terziev, D.; Zhang, D.; Zhou, P. Optimization of NPK fertilization combined with phytoremediation of cadmium contaminated soil by orthogonal experiment. Ecotoxicol. Environ. Saf. 2020, 189, 109997. [CrossRef] 